\title{
Nineteenth-
}

Century

Music Review

\section{Volume 7, Issue 1}

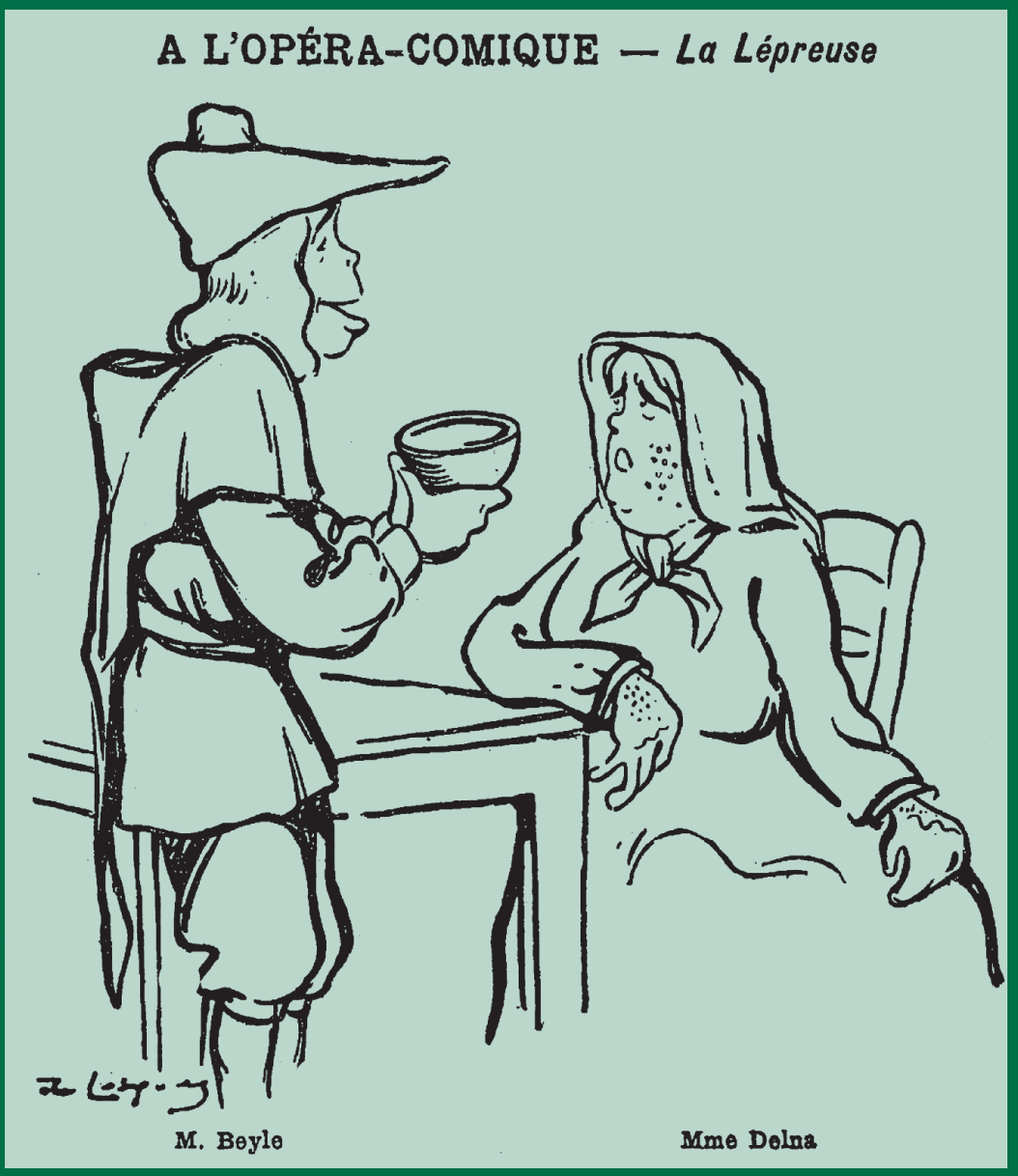




\title{
Nineteenth-Century Music Review
}

\section{VOLUME 7, ISSUE 1 \\ 2010}

\author{
ASHGATE \\ Published in association with the Centre for \\ Nineteenth-Century Music, Durham University, UK
}


Letters to the Editor For any communication concerning published articles or reviews, please send letters by email or hard copy to the General Editor:

Professor Bennett Zon

School of Music

Durham University

Palace Green

Durham DH1 3RL

England

Email: bennett.zon@durham.ac.uk

Subscriptions For the latest information about the price of the journal and details of how to subscribe, please contact:

Nicky Staszkiewicz

Ashgate Publishing Limited

Wey Court East

Union Road

Farnham

Surrey GU9 7PT

England

Tel: $+44(0) 1252736693$

Fax: +44 (0)01252 736736

Email: journals@ashgatepublishing.com

\section{Themed Issues}

The General Editor of Nineteenth-Century Music Review encourages proposals from individuals with ideas for themed issues, involving the commissioning of up to six main articles per issue, as well as one or more review articles for coverage of books, CDs and scores. Those applying to the journal for this purpose should initially provide the General Editor with a statement of no more than 500 words, outlining the thematic nature of the proposed issue, the names of contributing authors along with a working title for their papers, and a timetable for submission of work.

Proposers of themed issues work alongside the General Editor, and are designated Guest Editors. They are responsible for commissioning, organizing and preparing articles for publication, as well as working closely with review editors to locate suitable material and authors for relevant sections of the journal. Review sections of themed issues are not exclusively thematicized, and tend towards a balance of half themed, and half general material.

Articles commissioned for themed issues follow the same process of peer review as general issues. No guarantee of publication can be given to specially commissioned authors. 


\title{
Nineteenth-Century Music Review
}

\author{
General Editor \\ Bennett Zon \\ Book Reviews Editor \\ James William Sobaskie \\ CD Reviews Editor \\ Jeremy Dibble \\ Score Reviews Editor \\ R. Larry Todd
}

\section{Editorial Board}

Professor Bennett Zon, Durham University, UK (General Editor)

Professor Jeremy Dibble, Durham University, UK (CD Reviews Editor)

Professor R. Larry Todd, Duke

University, USA (Score Reviews Editor)
Dr James William Sobaskie, Mississippi State University, USA (Book Reviews Editor)

Professor William Weber, California State University, Long Beach, USA

Dr Phyllis Weliver, Saint Louis University, USA

\section{Advisory Board}

Dr Rosamund Bartlett

Professor Andrew Bowie, Royal Holloway, University of London,UK

Professor Anna Celenza, Georgetown University, USA

Dr Geoffrey Chew, Royal Holloway, University of London, UK

Professor John Deathridge, King's College, University of London, UK

Dr Steven Downes, University of Surrey, UK

Professor Peter Franklin, University of Oxford, UK

Dr Sophie Fuller

Professor Lydia Goehr, Colombia University, USA

Professor Thomas Grey, Stanford University, USA
Professor Hervé Lacombe, Université Rennes 2 - Haute Bretagne, France

Professor Roberta Marvin, University of Iowa, USA

\section{Professor Simon McVeigh,}

Goldsmiths College, University of London, UK

Professor Julian Rushton, University of Leeds, UK

Professor Jim Samson, Royal Holloway, University of London, UK

Professor Manuela Schwartz, Hochschule Magdeburg/Stendal (FH), Germany

Professor Nicholas Temperley, University of Illinois, USA 
All rights reserved. No part of this publication may be reproduced, stored in a retrival system, or transmitted in any form or by any means, electronic, mechanical, photocopying, recording or otherwise, without the prior permission of the publisher.

Published by

Ashgate Publishing Limited

Wey Court East

Ashgate Publishing Company

Union Road Suite 420

Farnham 101 Cherry Street

Surrey GU9 7PT Burlington, VT 05401-4405

England USA

This journal is the successor of the Music Review, founded by the late Geoffrey Sharp, which then continued for many years under the ownership of the late A.F. Leighton-Thomas.

www.ashgate.com

ISSN: $1479-4098$

Bach musicological font developed by (C) Yo Tomita MPG Books Ltd, Bodmin, Cornwall. 


\section{Contents}

Volume 7, Issue 1

Notes on Article Contributors

ix

\section{Articles}

Philip V. Bohlman

Herder's Nineteenth Century

Margaret Mehl

Japan's Early Twentieth-Century Violin Boom

Julie McQuinn

The Medieval Leper Plagues Modern Paris:

Sylvio Lazzari's La Lépreuse

Martin V. Clarke

The Illingworth Moor Singers' Book: A Snapshot of Methodist Music in the Early Nineteenth Century

Allan W. Atlas

Vaughan Williams's Songs of Travel: A Note on the Structural Role of the Thematic Recollections in Songs 4 and 9

\section{REviews}

Book Reviews

William Drabkin

Unfinished Music by Richard Kramer

Inside Beethoven's Quartets: History, Performance, Interpretation

by Lewis Lockwood and the Juilliard String Quartet

Angela R. Mace

Mendelssohn in Performance by Siegwart Reichwald

Julian Rushton

Form, Program, and Metaphor in the Music of Berlioz by Stephen Rodgers

Kenneth Stilwell

Schumann's Late Style by Laura Tunbridge 
David Trippett

After the Golden Age: Romantic Pianism and Modern Performance

by Kenneth Hamilton

Books Received

CD Reviews

Luke Woodhouse

Brahms: Symphony No. 4 in E minor Op. 90; Schoenberg:

Variations for Orchestra Op. 31. German Symphony Orchestra, Kent

Nagano cond. Brahms: Symphony No. 4 in E minor Op. 90;

Tragic Overture Op. 81; For Four Hands Vol. 8. Silke-Thora Matthies/

Christian Köhn pf

\section{Michael Allis}

English Piano Works: Sterndale Bennett: Sonata in F minor Op. 13;

William Thomas Best: Grande Mouvement de Danse: Polka Originale Op. 4; Romanesca Op. 16; C. Hubert H. Parry: Shulbrede Tunes.

Simon Callaghan $p f$, De Rode Pomp

Michael Murphy

Karłowicz: Symphonic Poems - 1: Stanisław i Anna Oświecimowie

Op. 12; Rapsodia litewska Op. 11; Epizod na maskaradzie (comp. Fitelberg)

Op. 14. Warsaw Philharmonic Orchestra, Antoni Wit cond

\section{Alasdair Jamieson}

Martucci: Complete Orchestral Music - 1: Symphony No. 1 in D minor Op. 75; Notturno Op. 70 No. 1; Andante Op. 69 No. 2; Canzonetta Op. 65 No. 2; Giga Op. 61 No. 3. Andrea Noferini vc, Orchestra Sinfonica di Roma, Francesco la Vecchia cond. Complete Orchestral Music - 2: Symphony No. 2 in F major Op. 81; Theme and Variations Op. 58; Tarantella Op. 44 No. 6; Gavotta Op. 55 No. 2. Lya De Barberlis pf, Orchestra Sinfonica di Roma, Francesco La Vecchia cond. Complete Orchestral Music - 3: Piano Concerto No.1 in D minor Op. 40;

La Canzone dei Ricordi. Gesualdo Coggi pnfte, Silvia Pasini mezzo; Orchestra Sinfonica di Roma; Francesco la Vecchia cond. Complete Orchestral Music - 4: Piano Concerto No. 2 in B, minor Op. 66; Momento Musicale e Minuetto; Novelletta Op. 82 No. 2; Serenata Op. 57 No. 2; Colore Orientale Op. 44 No. 3. Gesualdo Coggi pnfte, Orchestra Sinfonica di Roma, Francesco la Vecchia cond

David Larkin

Richard Strauss: An Alpine Symphony (Eine Alpensinfonie) Op. 64;

Staatskapelle Weimar, Antoni Wit cond 
CDs Received

Scores Received

Guidelines for Contributors 